\begin{tabular}{|l|l|l||}
\hline \multicolumn{2}{|c|}{ PublisherInfo } \\
\hline \hline PublisherName & $:$ & BioMed Central \\
\hline \hline PublisherLocation & $:$ & London \\
\hline \hline PublisherImprintName & $:$ & BioMed Central \\
\hline \hline
\end{tabular}

\title{
Gene clusters in the fly genome
}

\begin{tabular}{|l|l|l||}
\hline \multicolumn{2}{|c|}{ ArticleInfo } \\
\hline \hline ArticleID & $:$ & 4660 \\
\hline \hline ArticleDOI & $:$ & $10.1186 /$ gb-spotlight-20021213-01 \\
\hline \hline ArticleCitationID & $:$ & spotlight-20021213-01 \\
\hline \hline ArticleSequenceNumber & $:$ & 326 \\
\hline \hline ArticleCategory & $:$ & Research news \\
\hline \hline ArticleFirstPage & $:$ & 1 \\
\hline \hline ArticleLastPage & $:$ & 2 \\
\hline \hline & & RegistrationDate : 2002-12-13 \\
ArticleHistory & $:$ & OnlineDate \\
\hline \hline ArticleCopyright & $:$ & BioMed Central Ltd2002-13 \\
\hline \hline ArticleGrants & $:$ & \\
\hline \hline ArticleContext & $:$ & 130593311 \\
\hline \hline
\end{tabular}




\section{Jonathan B Weitzman}

Email: jonathanweitzman@hotmail.com

A number of studies have provided convincing evidence that co-expressed genes are often found in clusters in the yeast, fly, worm or human genomes. In the December 12 Nature Boutanaev et al. describe additional examples of clustering of Drosophila genes (Nature 2002, 420:666-669). Analysis of available databases of expressed sequence tags (ESTs) identified 4,271 genes expressed in the testes, of which 1,661 appear to be testis-specific. Mapping each EST to the fly genome revealed that about one third of testis-specific genes are clustered; many of these clusters (45\%) contain four or more genes. A notable exception was chromosome $\mathrm{X}$, which showed little clustering of testis-specific genes and smaller cluster sizes. Additional EST-based analysis also showed clusters of head-specific genes and embryonic genes. Much remains to be discovered about the role of chromatin structure in the transcriptional regulation of genome clusters.

\section{References}

1. A computational analysis of whole-genome expression data reveals chromosomal domains of gene expression.

2. Evidence for large domains of similarly expressed genes in the Drosophila genome.

3. Chromosomal clustering of muscle-expressed genes in Caenorhabditis elegans.

4. The human transcriptome map: clustering of highly expressed genes in chromosomal domains.

5. Nature, [http://www.nature.com] 